University of Nebraska - Lincoln

DigitalCommons@University of Nebraska - Lincoln

Space, Cyber, and Telecommunications Law

Program Faculty Publications

2002

\title{
Intellectual Property Rights as a Policy Tool for Earth Observation Data in Europe
}

Frans G. von der Dunk

University of Nebraska - Lincoln, fvonderdunk2@unl.edu

Follow this and additional works at: https://digitalcommons.unl.edu/spacelaw

Part of the Air and Space Law Commons

von der Dunk, Frans G., "Intellectual Property Rights as a Policy Tool for Earth Observation Data in Europe" (2002). Space, Cyber, and Telecommunications Law Program Faculty Publications. 19.

https://digitalcommons.unl.edu/spacelaw/19

This Article is brought to you for free and open access by the Law, College of at DigitalCommons@University of Nebraska - Lincoln. It has been accepted for inclusion in Space, Cyber, and Telecommunications Law Program Faculty Publications by an authorized administrator of DigitalCommons@University of Nebraska - Lincoln. 
Published (as chapter 6) in Earth Observation Data Policy and Europe, edited by Ray Harris (Lisse: A. A. Balkema, 2002), pp. 51-59. Copyright ( 2002 Swets \& Zeitlinger B.V. (Division of Taylor \& Francis). Used by permission.

\title{
Intellectual Property Rights as a Policy Tool for Earth Observation Data in Europe
}

\author{
Frans von der Dunk
}

International Institute of Air and Space Law, Leiden University, The Netherlands

\begin{abstract}
This chapter provides a contribution to analyze and evaluate the possibilities and obstacles of using intellectual property rights as a policy tool in the European Earth observation context. To this end, the generic concept of "intellectual property rights" will be discussed first. Secondly, such an analysis will then be applied to the legal particularities provided by Earth observation from space. Thirdly, a few international treaties on intellectual property rights will be discussed. Fourthly, the particular legal framework available in principle for any policies in Europe will be scrutinized, for example the specifics of the legal order having arisen within the European Union. Fifthly, the relevance of legislative efforts undertaken in Europe so far will also be scrutinized.
\end{abstract}

\section{Introduction}

This chapter provides a contribution to analyze and evaluate the possibilities and obstacles of using intellectual property rights as a policy tool in the European Earth observation context. The term "policy tool" in this regard should be understood as referring to the public entities available within Europe, i.e. most prominently the European Community as a partly supranational institution, ESA and EUMETSAT as international Earth observation organizations within Europe, and of course their respective member states. Any policy in the real sense of the word which would exercise a decisive impact upon the development of Earth observation and Earth observation data exploitation in Europe will have to be defined and executed within such a framework.

To this end, the generic concept of "intellectual property rights" will be discussed first. Secondly, such an analysis will then be applied to the legal particularities provided by Earth observation from space. Thirdly, a few international treaties on intellectual property rights will be discussed. Fourthly, the particular legal framework available in principle for any policies in Europe will be scrutinized, for example the specifics of the legal order having arisen within the European Union. Fifthly, the relevance of legislative efforts undertaken in Europe so far will also be scrutinized briefly. A conclusion will follow as to how intellectual property rights in the European context could contribute positively to Earth observation data policy in Europe. 


\section{The Legal Concept of Intellectual Property Rights}

"Property" in common parlance as much as in law is a concept relating to the ownership of something physical, and is of core importance in all domestic legal systems. Even in traditional communist law, where private ownership of immovable property, capital goods, and a number of other entities was anathema, "property" as such was a fundamental notion. In other societies, it was private "property," the rights derived therefrom and the duties attached thereto, which was, and is considered a cornerstone of society. Giving private persons and entities the opportunity to "own" something and protect such ownership by law provided legal, economic, and social predictability, and stimulated private entrepreneurship and careful treatment of the world around them which in turn was considered essential for social and economic development.

From the same underlying philosophy, it has long been considered essential for society to also protect non-physical assets. Generally, such non-physical property rights have been classified into two broad and generic categories: industrial property rights and intellectual property rights in a narrower sense. All these regimes essentially provide for a balance between the interests of the individual whose industrial or intellectual property is at stake, and the interests of society at large in being able ultimately to benefit from such property as well. This balance is influenced by such policy considerations regarding encouragement of public education and enlightenment, the assistance of economic development, and the protection of national security.

The category of intellectual property rights sensu stricto concerns, most prominently, copyrights, and additionally such neighboring rights as those related to production, editing and publishing, photographs, computer programs etc. This category has, in addition to a clear economic component, or perhaps more properly in addition to clear economic value, also an important moral component. Such moral rights primarily serve the immaterial interests of the author of texts, music, films, paintings, and any other entity requiring a certain talent in being recognized as such, and in opposing mutilation of his/her work, deciding from this perspective on proper forms of publication, alterations, or additions. Copyright is a limited form of property only, encompassing certain enumerated rights, which are statutorily reserved to the copyright holder, such as the rights to reproduce the work in copies, to prepare derivative works based on the original work, and to distribute copies to the public in order to exploit the product.

With reference to the aforementioned balance between the private interest of the creator and the public interest of society at large, broadly speaking two approaches may be discerned when considering, for example, copyrights. The European-continental approach is the more author-minded one, the explicit point of departure being that the author has a right to the fruit of his labor, which has its primary roots in the natural bond between author and the work he/she has created. At the same time, in general continental European copyright laws are alike in requiring originality, which is an important obstacle when it comes for example to Earth observation databases. The Anglo-American approach on the other hand is more utilitarian. Copyright is aimed at stimulating authors essentially for the purpose of allowing society to benefit from them, and to deal with them accordingly. At the same time, under Anglo-Saxon intellectual property rights law it suffices basically if skill and labor are involved, the "sweat of the brow" concept largely replacing the requirement of creativity of the author being perceptible in the work. This means that copy- 
right protection sensu stricto would be more readily available for Earth observation data products in Anglo-Saxon jurisdictions than in others.

Although collections, whether of items of information or data, are possible objects of copyright, the required originality in terms of Earth observation databases may prove to be prohibitive. In databases the selection and arrangement of the content must be original, but functional and technical demands would be prone to adversely affecting such originality. Databases might be protected by copyright if they constitute a personal original intellectual creation of the author, but this option might not be open for all databases. Hence, a special right concerning databases that are not eligible for copyright protection was developed, the right for producers to prevent extraction of data from their databases, the so-called "extraction right."

\section{Earth Observation and Intellectual Property Rights}

When it comes to the policy aspects of intellectual property rights, in other words, the extent to which intellectual property rights regimes can be used as a tool in the satellite Earth observation sector, for historic reasons the obvious point of departure is the domestic legal system. In this regard, it has to be further noted that national regimes on intellectual property rights are often focused on territory, if not also regarding the place of creation, then certainly as regards the enforcement of any relevant rules. Those cases where national intellectual property rights legislation is applied on a personal basis, i.e. to persons and entities with the nationality of the state concerned, result in inherent problems to the extent that extra-territorial application would arise.

This leads to a specific complication in the case of satellite Earth observation: the conception of data, even if only "raw," in outer space. The conception of data being the decisive and defining moment, the consequence here of the terra communis status of outer space, as following from Article II of the Outer Space Treaty, is that data conceived in outer space might not fall within the scope of intellectual property rights legislation to the extent that such legislation is domestic and terrestrial in character. Application of the policy tool of copyrights directly in outer space therefore does not look like a very promising approach.

On the other hand, all data "come down" (at least so far) to Earth in some territory or other, read within the jurisdiction of some state or other, and from that moment on it can certainly be dealt with by (national) copyright legislation. It is also in this phase that the transformation from raw data to a more readily usable enhanced data takes place by means of value adding. Consequently, here (further) opportunities arise to apply copyright or other intellectual property rights to Earth observation data products, even for those cases where such legislation is to be applied to nationals as such.

A second major problem arises, once the extension in scope of copyright to space-home data is identified or alternatively achieved, as to whether the particularities of generating Earth observation data would include it, or allow it to be included, within the particular terms of a copyright regime. In other words, does it qualify for copyright? Copyright might seem a good solution for also protecting producers of Earth observation data sets against free riding by competitors. However, copyright law usually requires some level of originality in the work, even if this is often effectively taking the form of "sweat of the brow" only. Copyright protects an original work of authorship or an original expression 
rather than ideas or facts. Many Earth observation data sets are primarily arrangements of factual data, and usually facts are not protected by copyright. Although the arrangement of the factual data might involve originality, or at least "sweat of the brow," it is insufficient in practice if only this is to be protected. Withdrawal of selected factual information from any data set would occur much more frequently than simply copying of whole data sets. Thus, although substantial effort may go into the compilation of data, much of their value would not be protected by copyright law.

Apart from being defined as facts. Earth observation data could in principle fall under the definition of photographs. Photographs or images produced by a process similar to photography do not qualify for copyright protection if they lack originality. However, a considerable number of states provide for a separate exclusive right for the photographer of such non-original photographs. This special right confers on the photographer the exclusive power to authorize duplication (and in some cases reproduction in altered form) and/or dissemination of photographs. The question of whether a photograph is original and thus copyrighted or non-original and eligible for special protection may be answered differently, depending on the national law involved. As a rule, aerial photographs or satellite images whose production can be said to be purely a "technical" achievement rather than a creative one are likely to lack the level of originality required for copyright protection. If a photograph is considered non-original, this does not automatically imply that it falls within the scope of special provisions: in some states photographs must show some element of creativity to be protected under the special provisions. Failing that, the photographs in question would not be protected at all.

A third interesting option concerns computer software (including computer-mapping systems) which can be sold, leased, or licensed for commercial use. Thus, computer programs could be regarded as works of literature, and copying and adaptation of software without the permission of the copyright owner would only be allowed in a limited number of cases, such as for storing it on hard disk or making back ups, for purposes of reverse engineering in order to produce interfaces, etc. These exceptions to the exclusive reproduction right are, however, either self-evident (back ups) or rather controversial (reverse engineering). Only computer programs that constitute an intellectual creation (i.e. original) would generally be eligible for copyright protection. For Earth observation data within Europe, this option would not alter much, since pursuant to the Community's software directive, computer programs that are used in, for instance, Geographical Information Systems (GIS) are already copyrighted if they are original.

Finally, the concept of databases would obviously lend itself to providing intellectual property rights protection to Earth observation data, and has been used as such. Regarding databases, collections of data or other materials fall within the scope of copyright, provided that due to the selection or arrangement of materials the database constitutes an intellectual creation (i.e. is original). In addition, non-original databases can be protected by a sui generis extraction right. The justification for such a right is that producers of databases should be able to protect their investments, by having the exclusive right to prevent (or authorize) extraction of data from their database and control subsequent (re)use of these data. 


\section{The Major International Treaties Dealing with Intellectual Property Rights}

The international patchwork of domestic laws on intellectual and industrial property rights caught the attention of the international community at an early date, resulting in important harmonizing efforts. A number of treaties have resulted, often achieving widespread ratification. A brief description of the major ones follows in order to provide the background against which any use of intellectual property rights as policy tools in the European context could be undertaken.

The Berne Convention of 1886 is the oldest and most important copyright treaty. The primary goal of the convention is to ensure international protection of works of literature, science, or art. Almost 130 countries are party to the Berne Convention. One of the main principles of the convention is the principle of "national treatment." This means that authors in each state that is a party to the convention are conferred the same rights as the nationals of that state have. Furthermore, the convention specifies the minimum rights that each state party to the convention must grant to nationals of other member states, the principle of "most favored nation." The central definition is that of literary and artistic works, which include "photographic works to which are assimilated works expressed by a process analogous to photography; works of applied art; illustrations, maps, plans, sketches and three-dimensional works related to geography, topography, architecture or science" (Article 2). To possibly fall under copyright, the work requires a minimum level of creative effort or originality. Collections of facts or raw data may be original, and thus copyright works, due to the selection and arrangement of the data.

The Universal Copyright Convention of 1952, enacted under the auspices of UNESCO is somewhat less important than the Berne Convention. More than 90 states are party to this convention. The level of protection offered by the Universal Copyright Convention is more or less supplementary to, albeit lower than, the minimum protection offered by the Berne Convention. Most states concerned are parties to both treaties. The Universal Copyright Convention is mainly important for the formalities to be fulfilled in order to invoke copyright protection. It essentially provides for the facilitation of the mutual recognition of copyright grants.

The Uruguay round of the negotiations on the General Agreement on Tariffs and Trade (GATT') resulted in 1995 in a global agreement on Trade Related Aspects of Intellectual Property Rights (the so-called TRIPs Agreement). It obliges over 120 states to implement the protection provided. The objective of the TRIPs Agreement is the same as that of the Berne Convention, to ensure international protection for all kinds of works, this time however including modern technology products such as databases and computer software. Parties are obliged to ensure the minimum level of protection granted by the Berne Convention. Thus, computer programs are protected as literary works.

1 Now the World Trade Organization - WTO. The GATT has been institutionalized, together with the General Agreement on Trade in Services (GATS), by means of the establishment of the World Trade Organization - WTO; Agreement Establishing the World Trade Organization (hereafter WTO Agreement), Marrakesh, done 15 April 1994, entered into force 1 January 1995; 33 ILM 1144(1994). 
In 1989 work started on a possible Protocol to the Berne Convention. This was thought proper because of new emerging information technologies and new kinds of use of copyrighted intellectual property. In December 1996 this work resulted in the World Intellectual Property Organization (WIPO) Copyright Treaty. It has some provisions that may be of importance for databases such as those of Earth observation data by establishing a sui generis extraction right. Computer programs are protected as literary works when they constitute original creations. Databases that are original by way of selection and arrangement are also considered intellectual creations, and thus copyrightable works, but the protection of non-original databases was not agreed upon.

Finally, one may note that in 1883 the Paris Convention on the protection of industrial property was concluded. Over 140 countries have acceded to the Convention. Although the Convention deals primarily with patent law, trademarks, model and design protection, it contains some provisions that might be useful for the protection of products of geographical information, including Earth observation data. If such a product is no longer, or not at all subject to intellectual property right, competition law may offer some protection. The Convention provides in this respect that member states should afford adequate protection against unfair competition. Unfair competition is defined as consisting of acts of competition contrary to honest practices in industrial or commercial matters.

\section{The European Community Legal Framework and Earth Observation}

The position of the European Community since the Treaty on European Union came into force as a constituent part of the European Union, represents a unique feature in the field of space activities in more ways than one. For example, in stark contrast to ESA, the Community became involved in European space activities primarily as a regulator, and has only relatively recently become a player. Moreover, the Community, once again in contrast to ESA, is involved with all economic activities in the widest sense of the word. Space activities therefore only constitute one amongst many topics from the point of view of the Community. While it may be an elephant in itself, in terms of space the Community still plays the role of a mouse in many respects.

With primary Community law created by the member states through the constituent treaties forming the basis, the Community organs jointly established the immense body of secondary Community law. Secondary Community law comprises Regulations, Directives and Decisions. Regulations are essentially laws on a European level: they are phrased in general terms and apply comprehensively (Article 249, 2nd sentence, EC Treaty). The same qualification as law applies to Directives to some extent, namely as far as the required end result is concerned: each state is free, however, to reach that end result in whatever way it sees fit (Article 249, 3rd sentence, EC Treaty). Finally, Decisions also provide binding law, but only upon those entities to which they are explicitly or implicitly directed (Article 249, 4th sentence, EC Treaty).

By means of primary and secondary Community law, the power of an individual state to legislate on economic issues has thus largely been transferred to, or at least been circumscribed at the Community level. The Community however has no territorial jurisdiction in a strict sense, since it has no sovereignty over territory. Any "territorially-based" 
jurisdiction of the Community applies indirectly to the territories of its member states only - and certainly not as such to outer space, as that would touch upon third states' rights under space law. The Community does not yet have the competence to register its own space objects under Article VII of the Registration Convention either, which might have offered it the possibility to exercise jurisdiction at least vis-à-vis certain Earth observation satellites. These facts circumscribe at the outset the possibilities under Community law to deal with satellite Earth observation.

Satellite Earth observation activities fall within the Community legal order essentially because (and to the extent that) they form a category of economic activities. From this perspective, a few fundamental regimes of Community law, upon closer view, would have an impact upon private space activities. The central and most comprehensive aim of Community integration remains the creation and maintenance of a common market. While only the internal market, being one side of the common market, was established in 1993, the result amounts to a free market regime. This regime in turn is based upon four freedoms, a competition regime, and harmonization of relevant national legislation. The four freedoms concerned are the freedoms of movement of goods, of persons, of services, and of capital. These economic freedoms, and the more elaborated rights and obligations established as a consequence, are territorially defined: they aim at movements across borders of the Community's member states. The free movement of goods resulting from satellite Earth observation activities within the Community has some impact on the playing field, although such impact is essentially indirect in nature. The free movement of services might include such Earth observation data-related activities as marketing and sales activities, as being terrestrial activities. However, as of yet, no steps have been taken to apply the free movement of the provision of services to Earth observation services proper.

A central element of the establishment of the internal market concerns the harmonization of national legislation by the Community legal regime. Article 95 of the EC Treaty provides for simplified procedures that may lead to mandatory harmonization of national laws as long as it is necessary for the achievement of the internal market. The scope of this particular mechanism to promote free trade, but also recognize the legitimate role played by national regulation within the Community framework of market regulation has furthermore widened considerably with the entry into force of the Treaty on European Union in 1993. This may become relevant also for the issue of intellectual property rights: in view of the potential competition-distorting effects of intellectual property rights, harmonization of national legislation on the issue might be called for.

These general features of the Community's legal machinery are applicable to private (and corporate) entities involved in satellite Earth observation activities, especially to the terrestrial ones. For such purposes also, the Community regime amounts to an exercise of territorial and national jurisdiction combined. Both "territorial" and "national" in a legal sense refer to the combined territories and the combined nationalities of the member states respectively, not to any single "European territory" or "European nationality" as such. The Community has jurisdiction on a territorial basis over all private entities operating on the territories of the member states. In principle, it can also exercise that jurisdiction with respect to those entities undertaking activities in or closely related to outer space. 


\section{Internationalization of Intellectual Property Rights Issues in Europe}

Within Europe the issue of intellectual property rights for Earth observation and Earth observation data has generally been considered a matter for ESA because of its role as a catalyst for space activities. Thus, according to Article III(3) of the ESA Convention, "the Agency shall, with regard to the resulting inventions and technical data, secure such rights as may be appropriate for the protection of its interests, of those of the Member States participating in the relevant program, and of those of persons and bodies under their jurisdiction."

The project regarding the establishment and operation of the International Space Station put ESA's regulatory potential to the test in this field. The major shortcomings of ESA in this context, from the point of view of private enterprise, stem from its circumscribed role in legal terms. The tools were provided to impose a certain regime only when ESA itself was an indispensable participant, for example in the ERS program. The opportunity to play such a role, however, is consistently diminishing with the increasing budget cuts on the national level for space programs, especially those undertaken within the ESA framework. It was at this point, when potential applications within Europe and even for European institutions themselves became a distinct probability, that the European Community came into the picture as a potential regulator.

In 1990, ESA started a research project on the legal problems of data protection, when it became clear that its own competencies were too limited for comprehensive action. The Commission became interested, in view of the possibility to use intellectual property rights as anti-competitive tools in view of Articles 81, 82, 86, and 87 of the EC Treaty. Such Community involvement had led inter alia to the establishment of the Convention on the grant of European Patents of 1973, the Convention for the European Patent for the common market of 1975, and the Agreement relating to Community patent of 1989. Such activities presented another example of the widening definition of "competition" and potential distortion thereof within the Community for regulatory purposes. These developments ultimately also led to more specific Community legislation on the issue. Some of the most relevant pieces of secondary Community law will therefore be discussed below, albeit briefly.

The Directive on the harmonization of the term of protection of copyright of 29 October 1993 provides for a term of protection for the lifetime of the author plus 70 years, as of 1 July 1995. The duration of copyright-related rights is set to 50 years after the first performance and after the first recording of a phonogram or film. It is also provided that copyright protection of photographic works is only possible if they are original. Member states retain the freedom to provide for some other sort of protection for non-original photographs, such as satellite photographs.

The Directive on privacy protection is also relevant for the use of Earth observation data. Although land data primarily focus on objects and not on natural persons (subjects), and the data might even be presented anonymously, an operator can often easily relate these data to natural persons. In most cases the law concerning privacy protection is therefore applicable to such data. This means that the purpose of data collection and further use of the data have to be specified. According to the Directive, the purpose should already be defined at the start of the data collection and it should be enforced during each step of future processing until the moment the data are destroyed. This requirement 
could cause various difficulties for the Earth observation sector, since one of the main targets of the Earth observation infrastructure has been to develop basic data sets, aimed at multi-purpose use and exchange. Strong legal protection of databases through strong privacy legislation, as much as through copyright and extraction rights, could provide barriers for the development of added value products.

The Directive on the legal protection of databases of 11 March 1996, finally, had to be implemented in the national laws of the member states before 1 January 1998. This directive provides for copyright protection for databases that are personal intellectual creations because of the selection and arrangement of the used data. Furthermore the directive provides for a sui generis regime of protection for compilations of data that are not original. A database that is the result of a substantial investment in qualitative or quantitative terms qualifies for protection through the new extraction right, which lasts for 15 years from completion of the database. The extraction right enables the maker of a collection of data to prohibit others to extract all or a substantial part of the data. The directive provides, in addition to the copyright protection to producers of databases, a socalled extraction right (a right sui generis) to prevent unauthorized retrieval and use of all or substantial parts of data from a database, provided the production of the contents of the database required considerable investments. The directive has been criticized strongly in (international) literature, since it would offer too much protection to producers of databases, hinder non-commercial use of databases, and interfere with the development of additional quality products.

\section{Conclusions}

The various copyrights discussed above seem to offer interesting opportunities as policy tools for the purpose of promoting a viable Earth observation data market within Europe. The Community has a number of effective legal tools at its disposal to work towards such a result, and of course has already used such means through the Directive on database protection.

It may be time to take a more general and broader approach towards copyrights than by means of specifically focused Directives only. The major drive behind Community involvement is the internal market, supposedly leading to a level playing field. Thus, especially anti-competitive use of intellectual property rights, overly restricting access to Earth observation data and stifling any market growth in that respect can be curbed by Community initiatives through the active application of the competition regime and harmonization of national legislation on intellectual property rights. Especially in the United States, a basic policy towards liberal access to data, including limitations on exclusive rights of copyright holders, seems to succeed in creating a healthy market in geographic information, of which Earth observation is an important component part. It should be noted that such efforts appear to counter a certain trend arising in Europe, where the exclusive rights of the creators are stressed at the expense of easy access and the interests of society in general. 